\title{
Host Country Brand Image and Political Consumerism: Th e Case of Russia 2018 FIFA World Cup
}

\section{Claudio Rocha and Fiona Wyse}

Claudio Rocha, $\mathrm{PhD}$, is a lecturer in sport management at the University of Stirling. His research interests include social impacts of sport mega-events hosted by developing nations.

Fiona Wyse is a master's student in Sports Management at the University of Stirling. Her research interests include sport events and human rights.

\begin{abstract}
The aim of this study was to investigate whether 2018 FIFA World Cup (FWC) consumers would engage in political consumerism to reduce a perceived dissonance between host country (Russia) brand image and FWC brand attributes. Literature has associated Russia-hosted sport mega-events (SME) with violations of human rights. Drawing on cognitive dissonance theory, we investigate UK consumers $(n=417)$ on their perceptions about Russia's brand image (cognitive and affective attributes) and FWC brand attributes before and after the event. Online questionnaires were used to collect data, which were analyzed via covariance-based structural equation modeling. Findings showed that intentions did not differ from behaviors of political consumerism toward 2018 FWC products. Lower evaluations of affective host image attributes led to more political consumerism. Higher perceptions of the FWC attributes led to less political consumerism. Results inform FIFA (and possibly other SME owners) on how poor human rights practices (affective attributes) may affect the consumption of their products. Results also inform hosts about ineffectiveness of associating themselves with brands like FWC without showing concerns about human rights.
\end{abstract}

Keywords: human rights, co-branding, sport mega-events, consumption boycott

http://doi.org/10.32731/SMQ.291.032020.05

The interaction between a sport mega-event (SME) brand and the host country's brand image can affect attitudes toward consumption of products related to the event. Recent research has analyzed the event-host city/country brand alliance from a positive perspective, assuming that co-branding should create consumption benefits for both brands (Gibson, Qi, \& Zhang, 2008; Knott, Fyall, \& Jones, 2017; Rocha \& Fink, 2017). However, the literature has not approached the possibility of a negative influence between brands. This approach represents a timely, contemporary, and important gap in the literature, because powerful sport governing bodies have awarded hosting rights to countries with allegedly poor human rights practices (Chappelet \& Parent, 2015). Between 2008 and 2022, the Olympic Games (OG) and the FIFA World Cup (FWC) have been or will be held in China (Beijing 2008 OG and
Beijing 2022 Winter OG), Russia (Sochi 2014 Winter OG and the 2018 FWC), and Qatar (the 2022 FWC) (Flemming, Luenich, Marcinkowski, \& Starke, 2017). The Human Rights Watch ${ }^{1}$ has criticized all these countries for committing at least (but usually more than) one of the five main human rights abuses: forced evictions, exploitation of workers, silencing of activists, intimidation of journalists, and discrimination of minorities (Worden, 2015). Therefore, the main argument of the current research is that a negative host country's brand image caused by poor human rights practices can interact with the event brand image and create an environment for political consumerism. Political consumerism has been defined as the deliberate (non-)

\footnotetext{
The Human Rights Watch is an international non-governmental organization that conducts research and advocacy on human rights. For more information, go to https://www.hrw.org/.
} 
consumption of brand-specific products for political or ethical reasons (Copeland, 2014).

In the era of social media and digital inclusion, negative human rights portraits can rapidly be disseminated (Joseph, 2012). During the hosting period of a SME, such portraits have shown potential to damage the host country's brand image (Burch, Pegoraro, \& Frederick, 2017; Kirilenko \& Stepchenkova, 2017). For example, Twitter discussion during Sochi 2014 Winter OG apparently created a negative image of Russia, because most international posts associated the country with topics like anti-LGBT policies, Pussy Riot, ${ }^{2}$ and armed conflict in Ukraine (Kirilenko \& Stepchenkova, 2017). In general, Sochi 2014 Winter OG and the 2018 FWC have created a media spotlight on Russia, which has been reported as a country with low human rights practices (Persson \& Petersson, 2014; Schofield, Rhind, \& Blair, 2018; Van Rheenen, 2014). Such practices are likely to be responsible for creating a negative brand image of the place. Previous studies have explored Sochi 2014 Winter OG, but little has been said about the 2018 FWC. They represent SMEs with potential to trigger public opinion. The FWC has reached a higher global status and attracted the attention of larger crowds around the world when compared to the Winter OG (Reiche, 2018). Moreover, the FWC promotes the association of a country as a whole, as the event is hosted in multiple cities. Therefore, Russia 2018 FWC represents a very timely and suitable case to investigate the relationship between host country's brand image (based on perceptions of human rights practices) and political consumerism.

Schofield et al. (2018) proposed that consumers of SMEs have acted with moral disengagement to justify hosts' low ethical standards (e.g., poor human rights practices) and buy products related to sport events. They defined moral disengagement as a process where people convince themselves to create a moral distance from unethical behaviors of hosts. This distance disables self-condemnation and allows consumption without feelings of guilt (Schofield et al., 2018). After reviewing the literature, we found no empirical evidence for moral disengagement. Alternatively, we have drawn on cognitive dissonance theory (CDT, Festinger, 1962) to propose that people may change their attitudes toward a SME if they hold negative opinions toward the host country's brand image. CDT posits that when individuals realize they have dissonant cognitions, they tend to change their attitudes and behaviors to attain consonance. Therefore, the aim of this study is

\footnotetext{
2 Pussy Riot is a Russian feminist protest rock group that has offered open opposition to President Vladimir Putin and his policies.
}

to investigate whether the 2018 FWC consumers would engage in political consumerism to reduce a perceived dissonance between host country (Russia) brand image and FWC brand attributes.

Sport marketing studies have not yet explored the possibility that consumers may be engaging in boycotts toward sport events as a response to unethical behaviors of hosts and/or owners. As a first step to fill this gap, we investigated political consumerism (Copeland, 2014). In the current research, we have focused on attributes of host country's brand image and attributes of the FWC brand to explain attitudes (and later behaviors) toward political consumerism. The literature has informed that, as antecedent of consumption, country image should distinguish between affective and cognitive factors (Wang, Li, Barnes, \& Ahn, 2012). This is particularly important because previous investigations have shown that human rights are linked to affective attributes of the country image but not necessarily to cognitive attributes (Roth \& Diamantopoulos, 2009; Wang et al., 2012). Because those links have not been tested in sporting contexts, we tested affective and cognitive brand images of Russia along with brand attributes of the FWC as antecedents of political consumerism toward the 2018 FWC.

Results of this research have theoretical and practical contributions for the field. From a theoretical point of view, testing negative influences between brands in a model based on cognitive dissonance may provide new insights for co-branding in sport events. Results should clarify if interaction between brands can lead to political consumerism. From a practical point of view, results of this research may inform SME owners and hosts about the importance of human rights practices to create brand equity for events. If poor human rights practices create a negative brand image for the host country and increase political consumerism, then owners and hosts may need to go beyond the strategy of improving the brand image of the event; they may need also to promote good human practices in their countries.

\section{Literature Review}

Country brand image is defined as "the unique, multi-dimensional blend of elements that provide the nation with culturally grounded differentiation and relevance for all of its target audiences" (Dinnie, 2008, p. 15). The theory behind brand image in relation to nations and destinations has emphasized that multidimensionality proposed by Dinnie (2008). For example, one of the most cited theoretical frameworks on destination image (e.g., Florek \& Insch, 2011; Hallmann \& Breuer, 2010) is Gartner's (1993) image formation process, which proposed that destination image depends 
on three components: affective (emotions), cognitive (knowledge), and conative (intentions to behave). To create a positive image among international audiences, countries have developed their images in association with popular SME, such as the OG and FWC (Florek, Breitbarth, \& Conejo, 2008; Gibson et al., 2008; Grix, 2013; Rocha \& Fink, 2017). Co-branding is the marketing theoretical concept behind this idea.

\section{Cobranding Association between Sport Mega-Events and Hosts}

The concept of co-branding has been analyzed in tandem with image fit (Florek \& Insch, 2011). Xing and Chalip (2006) proposed that image fit between a sport event and the host should create favorable attitudes toward both. Using Gartner's (1993) theoretical framework, Hallmann and Breuer (2010) created an image fit index, which took into consideration affective and cognitive components of both events and host places. They found that image fit between sport events and host places can affect future consumer behaviors (e.g., intentions to revisit the place). Therefore, a mediocre fit between the sport event and the host country can create problems for co-branding production.

In the context of Beijing 2008, for example, Florek and Insch (2011) labeled the fit between China and the OG as an "unfavorable match" to indicate a negative host image in association with a positive event image. They argue that, before and during Beijing 2008, China was a regime with a "flawed human rights record," which created a negative image of the country, which in turn misfit the positive image of the OG (p. 274). The misfit created problems for co-branding China and the OG. In the current study, we use a similar argument to investigate the co-branding process involving Russia and the FWC, considering that mediocre fit can sign for cognitive dissonance.

Recent research has focused on exploring positive impacts (benefits) for place brands from this association. For instance, Florek et al. (2008) conducted a pre-post analysis of the 2006 Germany FWC case. They found that close engagement with the 2006 FWC (people who traveled and attended the event in Germany) produced a positive change in the country brand image, which became more associated with feelings of safety, friendly people, and multi-cultural atmosphere. Grix and Houlihan (2014) described how hosting the 2006 FWC positively altered the international brand image of Germany, which had been tarnished in the past by the association with the World War II and the Nazi party.

Additionally, Grix and Houlian (2014) detailed why the London 2012 OG were far less effective (compared to the 2006 FWC) to change the brand image of the UK internationally. They suggested that, despite positive perceptions about London 2012, the association with the Games had little to offer in terms of changing the already robust international brand image of the United Kingdom (at least before the Brexit referendum).

Still exploring positive impacts of co-branding, Rocha and Fink (2017) tested whether the interaction between the Brazil brand (as the host of the Rio 2016 OG) and the Olympic brand would benefit the country as a tourism destination. Results showed that international tourists perceived the OG as a stronger brand than Brazil brand as a tourism destination. Based on this finding, if the brand interaction had been effective, the image transfer should benefit Brazil brand from the association with the OG brand (Blackett \& Boad, 1999). However, Rocha and Fink (2017) reported that the co-branding process produced fewer benefits to the country than expected. Individual attributes of Brazil brand as a tourism destination had a stronger effect on intentions to visit the country after the Games than the interaction (OG x Brazil) factor did. They conclude that the benefits from interacting with the OG brand may be fewer than expected to host countries.

Although the direction of image transfers has been rarely measured, most authors have assumed a transfer from the sport event to the country host entity (Bodet \& Lacassagne, 2012; Rocha \& Fink, 2017; Xing \& Chalip, 2006). In theory, countries may benefit from their association with SMEs, which are reported as having strong brands (Dahlén \& Lange, 2005). In the current research, we challenge this view to propose that negative transfers can also occur, and they can happen in both directions - not only from events to hosts but also from hosts to events.

Negative transfers can occur from SME governing bodies to hosts. The International Olympic Committee (IOC) and FIFA have had their brands constantly questioned for mal-governance practices and ethical issues. The IOC has been accused of ignoring social and environmental issues associated with hosting the OG (Gaffney, 2013; Giulianotti, 2004; Watt, 2013). Gaffney (2013) described how the IOC showed little concern to the environment when it allowed the construction of the Rio 2016 golf course in an environmentally protected area. Watt (2013) reported how the IOC ignored residents' social bonds when it supported the gentrification of Stratford, East London, to host the London 2012 OG. FIFA brand has been seriously damaged for constant accusations of mal-governance practices and corruption (Pielke Jr., 2013; Tomlinson, 2014). Pielke Jr. (2013) listed allegations of corruption associated with FIFA and its former president, Joseph Blatter. 
These allegations ranged from bribery in the selection of FWC hosts to payoffs for votes in presidential elections. Therefore, we should not ignore that hosts might have their country brands associated with SME owners and consequently tarnished by such association.

To consider that the direction of the transfer in the opposite direction (i.e., from the host to the SME) may be relevant, we should also make a distinction between the owner (i.e., FIFA or IOC) brand and the event brand. Despite the problems with owners' brands, the OG and the FWC brands have held positive evaluations from sport consumers (Grix, 2012; Rocha \& Fink, 2017). Therefore, we should not discard the possibility that a negative host country's brand image can damage SME brands. Co-branding with a host with poor human rights practices might create problems for SME brands. This is the focus of the current investigation. We argue that the case of Russia and the 2014 FWC represents a unique opportunity to investigate the negative effects of such co-branding association on the brand of the event. To support this statement, below we present some facts on how Russia has managed human rights issues and how such issues may have created problems not only to the country brand image but also to the brands of SMEs hosted there.

\section{Sport Mega-Events and Human Rights in Russia}

Before Sochi 2014 and the 2018 FWC, Russia hosted the Moscow 1980 OG, still as part of the Soviet Union. The responses to Moscow 1980 and Sochi 2014 differed. While the former suffered from a state boycott, the latter faced social criticisms (mainly related to Russian anti-gay laws) with no strong demonstration of organized opposition (Van Rheenen, 2014). Nevertheless, in both cases, much of the furor about Russia political controversies faded away once the Games began (Ekberg \& Strange, 2017). The US-led boycott of Moscow 1980 was reported as a result of the Soviet invasion of Afghanistan in 1979 (Tulli, 2016). In fact, calls to move the Games away from the Soviet Union started almost as soon as Moscow was announced as the host city in 1974. Those calls were mainly based on the country's repeated violations of human rights. They escalated further in 1978, with repression of minorities and dissidents, forced displacement of residents, and use of forced labor (Tulli, 2016). Since Moscow 1980, different actions have been proposed to deal with lack of respect for human rights associated with the OG (Ekberg \& Strange, 2017). From boycotts to more democratic options, none of the actions seemed to be effective against autocratic political regimes. Lenskyj (2016) affirmed that, if the sport-governing bodies that own the SMEs were serious about human rights, they would enforce a much stricter selection process of hosts, requiring that they abide by international human rights rules before getting hosting rights. As recent selection processes prove, this has not been the case.

Thirty four years after Moscow 1980, as the host of Sochi 2014, Russia was once more fraught with human rights concerns (Lenskyj, 2016). Recent allegations include intimidation, kidnapping, and assassinations of dissidents; participation in local conflicts (e.g., South Ossetian conflict ${ }^{3}$ ); and the persecution of minorities (particularly in the LGBT community) (Van Rheenen, 2014). Specifically, the persecution of LGBT people was a point of controversy with many athletes, some of whom decided to boycott the event, while others undertook protests (Davidson \& McDonald, 2018; Ekberg \& Strange, 2017). Like in the Moscow 1980 Games, the boycott (now, not at a state but at an individual level) seems to have had little impact on either how SMEs are awarded or how they are used to promote human rights (for an example of Beijing 2022, see Lenskyj, 2016). Lenskyj (2016) argued that the IOC should know that human rights are at risk in Russia when they awarded the Games to Sochi in 2007. However, the IOC has apparently decided to put commercial interests ahead of human rights, as in fact they did before, at least in Berlin 1936 and Beijing 2008 (Lenskyj, 2016; Van Rheenen, 2014).

Concerns about human rights in Russia has also mired the 2018 FWC. The media has published ongoing persecutions of LGBT people, illustrated by cases such as the stories of kidnapping and torture of gay men in Chechen areas (Peter, 2017). Beyond homophobia, a recent document reported 19 cases of discriminatory acts in the 2017/2018 season of the Russian football league, including monkey chants and neo-Nazi songs (Sova, 2018). Van Rheenen (2014) asserted that violations of human rights in Russia are institutionalized, as part of a larger conservative agenda led by President Putin. By the time of the 2018 FWC, Russia has been identified as an autocratic (Flemming et al., 2017), authoritarian (Lankina, Libman, \& Obydenkova, 2016), and totalitarian regime (Dawisha, 2015; Lenskyj, 2016). It remains to be investigated what effects (if any) these characteristics of the host country of the 2018 FWC might have had on people's willingness to consume (or not) products related to the event.

\footnotetext{
3 The South Ossetian conflict was a 2008 war between Georgia on one side and Russia and Russian allies (South Ossetia and Abkhazia) on the other.
} 


\section{Cognitive Dissonance}

Schofield et al. (2018) suggested that consumers of SMEs have acted with moral disengagement to justify hosts' low ethical standards and continue consuming products related to sport events. Disengagement disables self-condemnation and allows consumption (Schofield et al., 2018). In this investigation, alternatively, we have proposed that a dissonance between positive attitudes toward an event brand and negative perceptions of a host country's brand might lead people to change their attitudes toward the event consumption. We based our proposal on CDT (Festinger, 1962), which posits that human beings actively look for a balance between their cognitions (opinions, perceptions, attitudes). If a dissonance between two or more cognitions appears, they act to eliminate or at least to reduce such dissonance. Dissonance was defined as any state of discomfort associated with inconsistencies between relevant cognitions (Festinger, 1962). A state of discomfort exists because people tend to feel responsible for undesired consequences (Greenwald \& Ronis, 1978).

CDT has been improved over the years. Some original propositions have been refuted, while additional theoretical elements were introduced to explain how people deal with dissonant cognitions (Harmon-Jones \& Harmon-Jones, 2007). One of Festinger's original hypotheses that has been disconfirmed by later research (Greenwald \& Ronis, 1978) was the hypothesis that a person would avoid situations or would not look for information that might increase dissonance. Actually, people seem to look for more information to create a better portrait about what is happening in their environment (Greenwald \& Ronis, 1978). This seems to be particularly important nowadays, because we live in times when information can be obtained and spread very quickly. During the hosting period of a SME, positive and negative portraits have shown potential to rapidly promote or damage the host country's brand image (Burch et al., 2017; Kirilenko \& Stepchenkova, 2017). Therefore, we have no strong basis to assume that FWC consumers are either ignorant regarding what has happened in Russia in terms of human rights or morally disengaged from such issues.

Additionally, Harmon-Jones and Harmon-Jones (2007) proposed that dissonant cognitions would be better understood in the light of the action-based model of dissonance. This model proposes that dissonance evokes a negative affective state that signals to the person that something is not right. They proposed that, when people have that negative affective state, most people would behave to correct the problem. The problem of the 2018 FWC we are investigating in this study is a possible dissonance between positive FWC brand image and negative host country's brand image. The action-based model of dissonance suggested that a negative affective state might change not only attitudes but also behaviors toward the 2018 FWC. Such attitudes and behaviors may occur in difference spheres. For example, people can engage in organized-group manifestations, such as street protests and public riots against the event and/or the owner. The literature suggests that this strategy has had little effect in capturing the attention of FIFA and IOC to hosts' human rights issues in the past (Adams \& Piekarz, 2015). Alternatively, people can also decide to adopt a more personal approach to protest, not consuming products associated with the event and/or the owner.

Attitudes and behaviors in the sphere of individual consumption represent the focus of this investigation. From a sport marketing point of view, this option seems intuitive.

More than this, the focus on individual consumption attitudes and behaviors has potential to represent a much stronger argument to convince FIFA and IOC to take human rights seriously. As profit-oriented organizations, they may be little concerned about street manifestations, which gather a couple hundred people, at most. However, if hosts' human rights malpractices can affect consumption attitudes and behaviors toward their products, they might start seeing the problem differently.

\section{Political Consumerism}

Copeland (2014) described how consumption options have been increasingly used to demonstrate political positions. The use of political consumerism is closely related to post-materialist values. Inglehart (1981) showed that, from the 1970s, societies have drastically shifted what they value, from a materialist to a post-materialist emphasis, from physical sustenance and safety to sense of belonging, self-expression, and quality of life. Later, Inglehart (1997) proposed that quality of life in modern societies are related to post-materialist values, such as gender equality, respect to minority rights, fair work practices, and environment protection. Then, Copeland (2014) theorized that concerns with such post-materialist values should increase the chance of people engaging in political consumerism.

Copeland (2014) also informed that political consumerism has manifested through two types of consumer behavior strategies: boycott and buycott. While boycott represents the non-consumption as punishment for unethical behaviors of organizations, buycotts represent the consumption of certain products as a reward for ethical behaviors (Friedman, 2002). In non-sport industries, ethical consumption and use of political consumerism through both strategies are well 
reported in the literature (Friedman, 2002; Hoffmann \& Hutter, 2012). Hoffmann and Hutter (2012) reported that ethical consumption has become a popular topic in mainstream marketing literature, illustrated by the number of special issues in leading academic journals about the topic in the last decade (e.g., European Journal of Marketing in 2006 and 2011; Journal of Business Research in 2009; Journal of Consumer Behaviour in 2010). The sport marketing literature has not yet followed the same tendency. Although sport management scholars have explored ethical issues related to sport (mainly to sporting goods) production (e.g. Thibault, 2009), they have not yet explored political consumerism as an answer to such issues.

Most sport studies on ethical aspects have focused on how social corporate responsibility (e.g., Walker \& Kent, 2010) and cause-related sport marketing (e.g., Yuksel, McDonald, \& Joo, 2016) might have some influences on consumption habits. An exception in the sport marketing literature is the study of Kim and Heere (2012), who investigated Indian and Chinese consumers' intentions to consume Western sporting goods brands. They found that poor labor practices associated with brands like Nike, Adidas, and Reebok have little power to affect consumption habits of Chinese consumers, who are mainly looking to associate themselves with sport brands that could make them global citizens. These findings are consistent with Joergens (2006), who reported that ethical issues might have little (if any) effect on consumers' behaviors of fashion brands. Although the study was not intentionally related to sport brands, focus groups' respondents spontaneously mentioned Nike to exemplify how they would not be willing to boycott a brand just because they have been connected to unethical production conducts.

In the current study, we investigated political consumerism via boycott attitudes and behaviors toward the 2018 FWC in Russia. The historical negative image of Russia in terms of human rights (Schofield et al., 2018; Van Rheenen, 2014) indicated that boycott would be more likely to occur than buycott. We have focused on attributes of host country's brand image and attributes of the FWC brand to explain attitudes (and later behaviors) toward political consumerism.

\section{Method}

\section{Procedures}

Ethical approval was granted before collecting data. The online questionnaire was created and sent via Bristol Online Survey. The questionnaire contained five sections. The constructs and item wordings are in the first column of Table 1. In the first and second sections, Russia (host country) cognitive and affective attributes were measured, each one through five items, adapted from Wang et al. (2012) and responded on a 7 -point agreement scale (from $1=$ strongly disagree to 7 = strongly agree). The stem for items in these scales reads, "Please express your level of agreement with the following statements: In my opinion, Russia is/has ..." Wang et al. reported very good reliability and validity measures for cognitive $(\alpha=.90 ; \rho=.90 ; A V E=.65)$ and affective $(\alpha=.89 ; \rho=.90 ; A V E=.65)$ country image attributes. From the original scale of Wang et al. (2012), we have used five items to measure cognitive and three items to measure affective country image. Based on the literature review (e.g. Schofield et al., 2018; Van Rheenen, 2014), we have added two items (one about freedom and another about human rights) to the affective country image scale.

In the third section, FWC brand attributes were measured on a semantic differential scale with seven bipolar adjectives (e.g., $1=$ boring, 7 = exciting), based on Shank and Beasley (1998). The stem for items in this scale reads, "To me, the FIFA World Cup is ..." To avoid the same method bias (Podsakoff, MacKenzie, Lee, \& Podsakoff, 2003), we opted for two different scales to measure Russia attributes and FWC attributes. Affective and cognitive attributes of Russia were measured as two distinct dimensions, as originally proposed by Wang et al. (2012). Affective (first three items) and cognitive (four last items) attributes of the FWC were also measured (Shank and Beasley, 1998).

In the fourth section, political consumerism was measured through five items, created after Copeland (2014) and responded on a 6-point agreement scale (from $1=$ strongly disagree to $6=$ strongly agree). The stem for these items reads, "Please express your level of agreement with the following statements: All things being considered ..." To measure both intentions (before the FWC) and behaviors (after the FWC), we modified the items in this scale depending on the time we collected data. For example, before the FWC, the first item read, “... I would never buy a 2018 FIFA World Cup souvenir." After the FWC, the item read, “... I have not bought a 2018 FIFA World Cup souvenir” (see Table 1 for all item wordings). The last section measured demographic characteristics of respondents.

\section{Participants}

Data were collected a month before $(n=258)$ and a month after $(n=159)$ the Russia 2018 FWC. Respondents $(n=417)$ were invited from a British university website to respond to an online questionnaire about the 2018 FWC and Russia, the host. Both sample sizes attended Anderson and Gerbing's (1988) criterion of at least 150 subjects to test structural models (Hair, Black, Babin, \& Anderson, 2009; Landis, Beal, \& Tesluk, 
Table 1. Scales, Items, Factor Loadings ( $\lambda$ ), Average Variance Explained (AVE), Cronbach's $a$, Composite Reliability $(\rho)$, Means (M), and Standard Deviations (SD) Before and After the 2018 FIFA World Cup

\begin{tabular}{|c|c|c|c|c|c|c|c|c|c|c|c|c|}
\hline & \multicolumn{6}{|c|}{ Before 2018 FWC } & \multicolumn{6}{|c|}{ After 2018 FWC } \\
\hline & $\lambda$ & AVE & $a$ & $\rho$ & $\mathbf{M}$ & SD & $\lambda$ & AVE & $a$ & $\rho$ & $\mathbf{M}$ & SD \\
\hline $\begin{array}{l}\text { Host country's brand image: Cognitive } \\
\text { attributes }\end{array}$ & & 0.673 & 0.884 & 0.885 & 3.67 & 1.15 & & 0.610 & 0.860 & 0.862 & 4.11 & 1.16 \\
\hline Affluent & 0.794 & & & & 3.88 & 1.50 & 0.734 & & & & 4.29 & 1.46 \\
\hline Economically well-developed & 0.866 & & & & 3.72 & 1.48 & 0.809 & & & & 4.38 & 1.50 \\
\hline High living standards & 0.905 & & & & 3.19 & 1.32 & 0.817 & & & & 3.56 & 1.48 \\
\hline Advanced technology & 0.610 & & & & 4.29 & 1.35 & 0.639 & & & & 4.76 & 1.40 \\
\hline Good standard of life & 0.892 & & & & 3.27 & 1.30 & 0.884 & & & & 3.62 & 1.42 \\
\hline $\begin{array}{l}\text { Host country's brand image: Affective } \\
\text { attributes }\end{array}$ & & 0.721 & 0.893 & 0.893 & 2.52 & 1.08 & & 0.731 & 0.909 & 0.910 & 2.63 & 1.21 \\
\hline Peace loving & 0.862 & & & & 2.62 & 1.24 & 0.904 & & & & 2.72 & 1.42 \\
\hline Friendly to minorities & 0.907 & & & & 2.18 & 1.23 & 0.876 & & & & 2.30 & 1.43 \\
\hline A free society & 0.856 & & & & 2.34 & 1.22 & 0.855 & & & & 2.47 & 1.32 \\
\hline Likeable & 0.727 & & & & 3.29 & 1.46 & 0.798 & & & & 3.17 & 1.49 \\
\hline Highly concerned with human rights & 0.883 & & & & 2.16 & 1.26 & 0.839 & & & & 2.45 & 1.38 \\
\hline World Cup attributes & & 0.738 & 0.940 & 0.938 & 4.34 & 1.65 & & 0.744 & 0.932 & 0.933 & 5.46 & 1.39 \\
\hline Boring vs Exciting & 0.878 & & & & 4.46 & 2.14 & 0.873 & & & & 5.73 & 1.67 \\
\hline Uninteresting vs Interesting & 0.896 & & & & 4.41 & 2.13 & 0.908 & & & & 5.56 & 1.79 \\
\hline Unappealing vs Appealing & 0.916 & & & & 4.44 & 1.98 & 0.864 & & & & 5.62 & 1.66 \\
\hline Worthless vs Valuable & 0.836 & & & & 4.41 & 1.72 & 0.875 & & & & 5.33 & 1.66 \\
\hline Useless vs Useful & 0.815 & & & & 4.12 & 1.65 & 0.785 & & & & 5.20 & 1.59 \\
\hline Irrelevant vs Relevant & 0.860 & & & & 4.22 & 1.86 & 0.837 & & & & 5.35 & 1.57 \\
\hline Important vs Unimportant & 0.808 & & & & 4.23 & 1.85 & 0.892 & & & & 5.33 & 1.62 \\
\hline Political consumerism & & 0.757 & 0.904 & 0.889 & 4.49 & 1.22 & & 0.481 & 0.742 & 0.743 & 4.55 & 0.92 \\
\hline $\begin{array}{l}\text { I would never buy a } 2018 \text { FIFA World } \\
\text { Cup souvenir }\end{array}$ & 0.963 & & & & 4.86 & 1.38 & & & & & & \\
\hline $\begin{array}{l}\text { I have not bought a } 2018 \text { FIFA World } \\
\text { Cup souvenir }\end{array}$ & & & & & & & 0.531 & & & & 5.26 & 1.34 \\
\hline $\begin{array}{l}\text { I would not wear a } 2018 \text { World Cup } \\
\text { licensed product (e.g., t-shirt) }\end{array}$ & 0.920 & & & & 4.76 & 1.50 & & & & & & \\
\hline $\begin{array}{l}\text { I have not used a } 2018 \text { World Cup } \\
\text { licensed product (e.g., t-shirt) }\end{array}$ & & & & & & & 0.508 & & & & 5.26 & 1.43 \\
\hline $\begin{array}{l}\text { I would not give a } 2018 \text { FIFA World Cup } \\
\text { souvenir to a friend }\end{array}$ & 0.825 & & & & 4.67 & 1.50 & & & & & & \\
\hline $\begin{array}{l}\text { I have not given a } 2018 \text { FIFA World Cup } \\
\text { souvenir to a friend }\end{array}$ & & & & & & & 0.580 & & & & 5.62 & 0.79 \\
\hline $\begin{array}{l}\text { I do not support the sponsors of the } \\
2018 \text { FIFA World Cup }\end{array}$ & 0.782 & & & & 4.65 & 1.34 & & & & & & \\
\hline $\begin{array}{l}\text { I have not supported the sponsors of the } \\
2018 \text { FIFA World Cup }\end{array}$ & & & & & & & 0.778 & & & & 4.02 & 1.59 \\
\hline $\begin{array}{l}\text { I would have negative things to say } \\
\text { about the } 2018 \text { FIFA World Cup }\end{array}$ & 0.847 & & & & 3.72 & 1.57 & & & & & & \\
\hline $\begin{array}{l}\text { I have said negative things about the } \\
2018 \text { FIFA World Cup }\end{array}$ & & & & & & & 0.961 & & & & 2.38 & 1.34 \\
\hline
\end{tabular}


2000). Wolf, Harrington, Clark, and Miller (2013) noticed that sample size recommendations for SEM varies from 40 to 240 . The current tested models were quite simple. Although desirable, they did not require larger samples. The university website is the portal students and staff use to have access to university links and resources. It has a constant link inviting users to participate in surveys conducted by scholars and students of the university. The participants were encouraged to send the link to friends and colleagues they thought might be interested in the 2018 FWC, characterizing the use of snowball sampling technique (Biernacki \& Waldorf, 1981). In both moments (before and after the 2018 FWC), participants were recruited using the same procedures. In the first data collection, respondents were mostly female (60\%), British (44\%), with a higher education (HE) diploma (84.6\%) and average age of 31.9 years $(S D=11.8)$. In the second data collection, respondents were mostly male (60\%), British (41\%), with an HE diploma (52\%), and average age of 25.1 years $(S D=9.3)$. We used gender, nationality, education, and age as control variables to test the models. Gender $(1=$ female; $0=$ male $)$, nationality $(1=$ British; $0=$ international $)$, and education ( $1=$ HE diploma; 0 = no HE diploma) are dummy-coded variables. Those demographic variables were used as control variables because the literature review does not support hypotheses about the relationship between them and the focal variables of the current study (political consumerism, brand image perceptions). However, considering that demographic differences might affect attitudes and behaviors, we use them as control variables to avoid nuisance in the relationship between the focal variables (Breaugh, 2008).

\section{Data Analysis}

We started data analysis comparing two measurement models via confirmatory factor analysis (CFA). This was necessary because we have found two theoretical approaches in the literature regarding attributes of brand image of sport entities (including events). Originally, some studies have proposed two distinct factors, represented by affective and cognitive attributes (Shank \& Beasley, 1998; Wang et al., 2012). However, recent studies have found that, when associated to sport entities, affective and cognitive items load better in only one dimension (Mutter \& Pawlowski, 2014; Tokuyama \& Greenwell, 2011). Therefore, we tested a model with a second-order latent variable (FWC attributes), represented by two first-order latent variables (affective attributes and cognitive attributes). Then, we tested a second model, where all items loaded in a first-order latent variable (FWC attributes). After identifying the best structure, we analyzed the data using covariance-based structural equation modeling, based on the two-step approach by Anderson \& Gerbing (1988).

In the first step, the psychometric properties of scales were assessed through a CFA, using $\chi^{2} / d f$, Tucker-Lewis Index (TLI), comparative-of-fit-index (CFI), and root mean square error of approximation (RMSEA) as fit indices. The internal consistency was measured through Cronbach's $\alpha$ and the reliability through composite reliability $(\rho)$. Convergent validity was informed by average variance extracted (AVE), while discriminant validity by comparing the AVE of each construct against the squared correlations between that construct and all others (following Fornell and Larcker, 1981). In the second step, two structural models were tested using the same fit indexes and analyzing the path coefficients (Figure 1). Model 1 considers the direct effects of FWC attributes, host country cognitive and affective attributes. Model 2 adds the interaction terms between FCW attributes and host country attributes. Two interaction terms were created by computing and multiplying latent factor scores of (a) FWC attributes and host country cognitive image and (b) FWC attributes and host country affective image, following Joreskog's (2000) procedures. We chose Joreskog's factor scores because they represent a full information method, which does not require either the introduction of products of observed variables or the imposition of nonlinear constraints (Schumacker, 2002). Therefore, the method is useful to test complex structural equation models with interaction terms. We tested both models before (attitudes) and after (behaviors) the 2018 FWC.

We have also applied $t$-tests to investigate the differences between before and after in our focal variables: cognitive and affective Russia brand image, FWC attributes, and political consumerism (intentions v. behaviors).

\section{Results}

The first measurement model (second-order FWC attributes; two first-order latent variables: affective attributes and cognitive attributes) presented poorer fit indices when compared to the second measurement model (first-order FCW attributes). The first measurement model presented the following fit indices: before $\left(\chi^{2} / d f=2.89 ; C F I=.961 ; T L I=.957 ;\right.$ RMSEA [90\% $C I]=.086[.080 ; .092] ; p$-close $<.001 ; A I C=23421.1)$ and after the $2018 \mathrm{FWC}\left(\chi^{2} / d f=2.41 ; C F I=.942 ; T L I\right.$ $=.935 ;$ RMSEA $[90 \% C I]=.095[.087 ; .103] ;$-close $<$ $.001 ; A I C=13604.1)$. The second measurement model fit the data better: before $\left(\chi^{2} / d f=2.32 ; C F I=.973 ; T L I\right.$ $=.970 ;$ RMSEA $[90 \% C I]=.072[.065 ; .078] ; p$-close $<$ $.001 ; A I C=23027.8)$ and after the $2018 \mathrm{FWC}\left(\chi^{2} / d f=\right.$ 

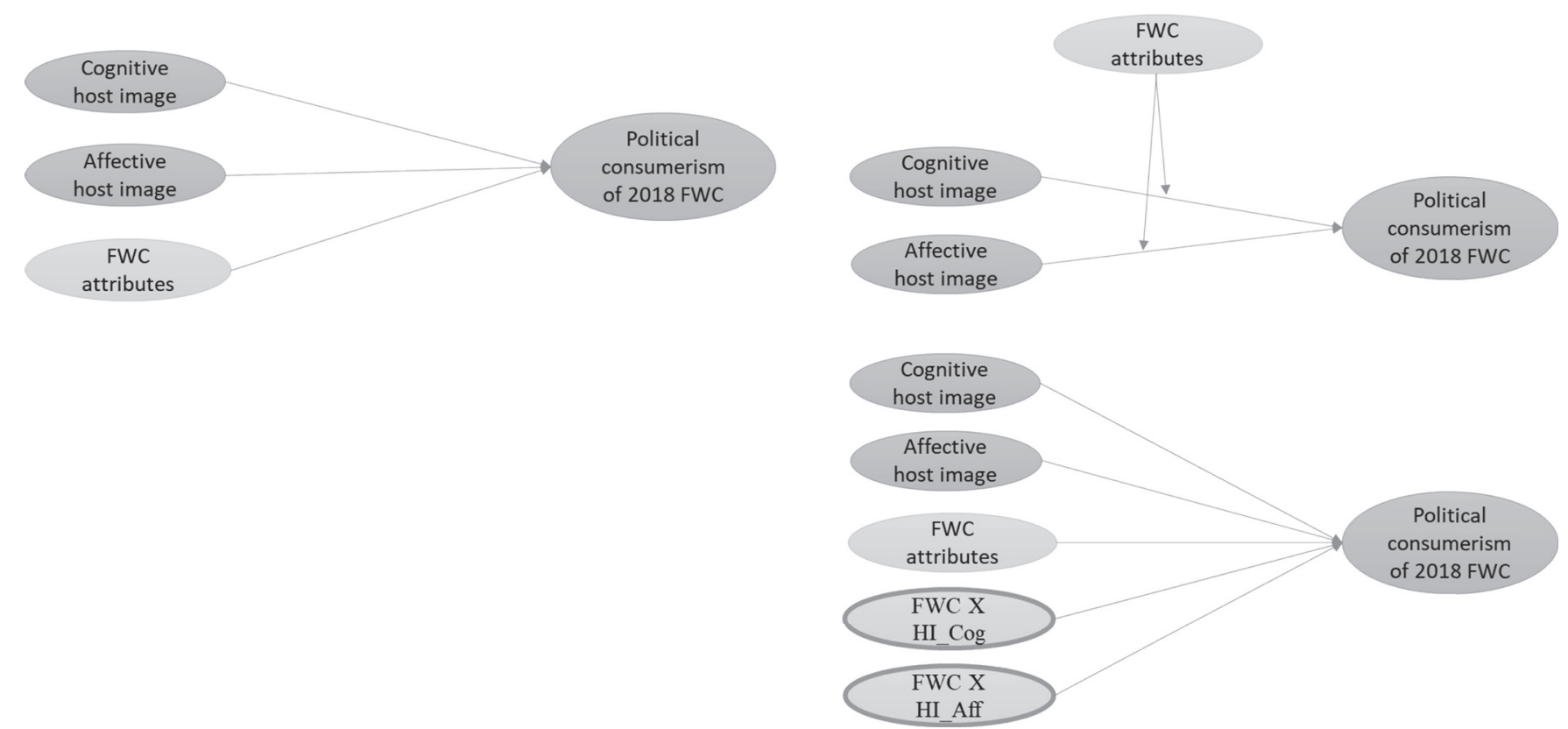

Figure 1. Two models to test the relationship among host country's brand images (cognitive $=$ HI_Cog and affective $=$ HI_Aff), FIFA World Cup (FWC) attributes, and political consumerism toward the 2018 FWC

$1.90 ; C F I=.961 ; T L I=.956 ; R M S E A[90 \% C I]=.076$ [.067; .084]; $p$-close <.001; AIC = 13433.9). Therefore, we adopted the second measurement model and considered FWC attributes as a unidimensional construct. Cronbach's alphas and composite reliabilities indicate good internal consistency before ( $\alpha$ ranging from .884 to $.930 ; \rho$ ranging from .885 to .938 ) and after ( $\alpha$ ranging from .742 to .932; $\rho$ ranging from .743 to .933). AVE of all constructs were above .50, indicating good convergent validity. The exception was political consumerism after the event, whose AVE was slightly below. Instead of deleting items to increase the AVE, we decide to keep the original scale because the scale worked well before the event; the AVE after the event was very close to .50, and all factor loadings were significant and above .500 (Tabachnick \& Fidell, 2007). Construct correlations ranged from $|.158|$ to $|.550|$ before the event and from |.111| to |.494| after the event. Therefore, all AVEs were larger than the squared correlations between pairs of constructs before and after the event, indicating no concerns with discriminant validity. For the political consumerism scale, we operationalize the items as negative sentences to follow the theoretical definition of boycott consumerism by Copeland (2014). Boycott means people would not buy something. The items showed good psychometric properties as scales to measure the construct before (intentions) and after (behaviors) an event. The values of Cronbach's alpha, composite reliability ( $r h o$ ), and AVE informed about the appropriate internal consistency, reliability, and convergent validity of the scales. Factor loadings, AVE, Cronbach's alphas, and descriptive statistics (mean and standard deviation) of each scale are in Table 1. Descriptive results showed that, before the event, respondents had low cognitive $(M=$ $3.67 ; S D=1.15)$ and even lower affective $(M=2.52$; $S D=1.08)$ perceptions about Russia brand attributes. After the event, cognitive $(M=4.11 ; S D=1.16)$ and affective $(M=2.63 ; S D=1.21)$ perceptions about host country brand attributes improved a little bit. Results of a $t$-test showed significant differences between before and after for cognitive $(t=3.87, p<.001)$ but not for affective $(t=1.02, p=.307)$ perceptions about Russia brand image.

Before the event, respondents expressed moderate perceptions about FWC brand attributes $(M=4.34$; $S D=1.65)$ and political consumerism intentions $(M=$ 4.49; $S D=1.22)$. After the event, respondents reported higher perceptions about FWC brand attributes $(M=$ 5.46; $S D=1.39$ ), but political consumerism behaviors $(M=4.55 ; S D=0.92)$ were close to the reported intentions. Results of $t$-tests showed significant differences between before and after for perceptions about FWC brand $(t=7.13, p<.001)$ but nonsignificant differences between political consumerism intentions and behaviors $(t=0.55, p=.584)$. 
Table 2. Comparing Model 1 (no interactions) with Model 2 (interactions) in the Path Estimates Before and After the 2018 FWC to Predict Political Consumerism of the 2018 FIFA World Cup

\begin{tabular}{|c|c|c|c|c|c|c|c|}
\hline & & \multicolumn{3}{|c|}{ Model 1: No interactions } & \multicolumn{3}{|c|}{ Model 2: Interactions } \\
\hline & & Estimate & SE & $p$ & Estimate & SE & $p$ \\
\hline \multirow{5}{*}{ 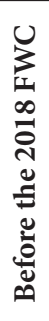 } & World Cup attributes (FWC) & -0.791 & 0.211 & $<.001$ & -0.704 & 0.172 & $<.001$ \\
\hline & $\begin{array}{l}\text { Host country cognitive attributes } \\
\text { (HI_Cog) }\end{array}$ & -0.042 & 0.116 & 0.717 & 0.051 & 0.104 & 0.623 \\
\hline & $\begin{array}{l}\text { Host country affective attributes } \\
\text { (HI_Aff) }\end{array}$ & -0.598 & 0.105 & $<.001$ & -0.655 & 0.107 & $<.001$ \\
\hline & FWC X HI_Cog & & & & -0.158 & 0.118 & 0.180 \\
\hline & FWC X HI_Aff & & & & 0.169 & 0.124 & 0.171 \\
\hline \multirow{5}{*}{ 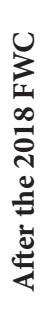 } & World Cup attributes (FWC) & -0.649 & 0.108 & $<.001$ & -0.606 & 0.207 & 0.003 \\
\hline & $\begin{array}{l}\text { Host country cognitive attributes } \\
\text { (HI_Cog) }\end{array}$ & 0.079 & 0.085 & 0.350 & 0.101 & 0.175 & 0.566 \\
\hline & $\begin{array}{l}\text { Host country affective attributes } \\
\text { (HI_Aff) }\end{array}$ & -0.242 & 0.090 & 0.008 & -0.326 & 0.151 & 0.030 \\
\hline & FWC X HI_Cog & & & & 0.211 & 0.165 & 0.202 \\
\hline & FWC X HI_Aff & & & & -0.096 & 0.102 & 0.346 \\
\hline
\end{tabular}

The structural model 1 (Figure 1, left side) showed acceptable fit indices before $\left(\chi^{2} / d f=2.32 ; R M S E A\right.$ [90\% $C I]=.072[.065 ; .078] ; C F I=.973 ; T L I=.970)$ and after the event $\left(\chi^{2} / d f=2.00 ; R M S E A[90 \% C I]=.080[.071\right.$; .088 ]; $C F I=.959 ; T L I=.954)$. Adding the interactions terms, the structural model 2 (Figure 1, right side) showed poorer fit indices before $\left(\chi^{2} / d f=2.48\right.$; RMSEA $[90 \% C I]=.076[.057 ; .095] ; C F I=.973 ; T L I=.964)$ and after the event $\left(\chi^{2} / d f=2.37 ; R M S E A[90 \% C I]=.094\right.$ $[.065 ; .112] ; C F I=.956 ; T L I=.940)$. The interactions in both moments were no predictors of political consumerism (Table 2). Based on this, we have no support to propose a model with interaction terms.

Results of the direct effects model were quite consistent: The path coefficients from FWC attributes and host country affective attributes to political consumerism were negative and significant before $(\gamma=-0.791 ; p$ $<.001 ; \gamma=-0.598 ; p<.001)$ and after $(\gamma=-0.649 ; p<$ $.001 ; \gamma=-0.242 ; p=.008)$ the event. Our interpretation is that (a) higher perceptions of the FWC attributes led to less political consumerism attitudes and behaviors and (b) lower evaluations of affective host image attributes led to more political consumerism attitudes and behaviors. Evaluation of cognitive host country image attributes was not a predictor of political consumerism attitudes and behaviors. These results take into consideration the control for demographic variables (gender, nationality, education, and age) before $\left(\gamma_{\mathrm{gen}}=0.493 ; p\right.$ $=.025 ; \gamma_{\text {nat }}=0.383 ; p=.084 ; \gamma_{\text {edu }}=0.182 ; p=.561$; $\left.\gamma_{\mathrm{age}}=0.022 ; p=.035\right)$ and $\mathrm{after}\left(\gamma_{\mathrm{gen}}=0.733 ; p=\right.$ $.001 ; \gamma_{\text {nat }}=0.236 ; p=.287 ; \gamma_{\text {edu }}=0.143 ; p=.487$; $\left.\gamma_{\text {age }}=0.025 ; p=.012\right)$ the event.

\section{Discussion}

The aim of this study was to investigate whether 2018 FWC consumers would engage in political consumerism to reduce a perceived dissonance between host country (Russia) brand image and FWC brand attributes. To attain this aim, we tested two models. We found no support for a model with interaction terms between host country's brand image (cognitive and affective attributes) and FWC brand attributes (the moderator between host country's brand image and political consumerism). This finding limited the discussion on how the spillover effect (Baumgarth, 2004) might have affected intentions and behaviors of political consumerism. Previous studies in the sport marketing literature have supported the existence of spillover effects in a variety of dyads: players and leagues (Shapiro, DeSchriver, \& Rascher, 2017), teams and leagues (Kunkel, Funk, \& Hill, 2013), sponsors and leagues (Cobbs, Groza, \& Rich, 2016), and different sponsors of the same sport entity (Cobbs et al., 2016). The current study adopted a different design and explored how possible spillover effects between a SME (the 2018 FWC) and a host (Russia) could have affected consumers' attitudes (political consumerism). Likewise, Rocha and Fink (2017) investigated how the spillover effects between the Rio 2016 Olympic Games and Brazil, the host country, could have affected consumers' attitudes (future tourism behaviors). They also found little support for the influences of a spillover effect on consumers' attitudes. Comparing the results of Rocha and Fink and the current ones with those of other studies in the literature seems to indicate that the context matters. That is, spill- 
over effects might be less likely to happen in the dyad sport mega-event and host brands than in other dyads (e.g., players/leagues, teams/leagues, and sponsor/ sponsor of the same sport league). However, the design of the studies should also be taken into account. While previous studies have focused on describing spillover effects (i.e., how brands may influence each other), this study (and Rocha \& Fink) investigated whether the interaction between brands could affect intentions and behaviors of sport consumers.

It is worth noting that, even not considering the interaction term (as in the direct effects model), the perception of both brands individually affected political consumerism intentions (before) and actual behaviors (after). Below we discuss the direct effects model, where both FWC brand attributes and Russia affective image brand led to behaviors of political consumerism. This model fits the data better than the model with an interaction factor. The direct effects model showed a negative and significant directional relationship from FWC brand attributes and Russia affective brand attributes to political consumerism intentions and behaviors. The lack of a significant relationship between Russia cognitive brand attributes and political consumerism is not surprising. Previous investigations have shown that human rights are linked to affective perceptions of the country image but not necessarily to cognitive perceptions (Roth \& Diamantopoulos, 2009; Wang et al., 2012).

\section{Russia Affective Brand Image and Political Consumerism}

The lower respondents evaluated Russia affective attributes (e.g., peace loving, friendly to minorities, concerned with human rights), the more they reported political consumerism intentions (e.g., I would never buy a 2018 FIFA World Cup souvenir) and behaviors (e.g., I have not bought a 2018 FIFA World Cup souvenir). These findings supported the assumption that the historical negative image of Russia in terms of human rights (Schofield et al., 2018; Van Rheenen, 2014) has had potential to trigger a boycott toward consuming products related to an event hosted in the country. Perceptions about respect for human rights is a post-materialist value (Inglehart, 1981). The literature has shown that concerns with post-materialist values increase the chances of people engaging in political consumerism (Copeland, 2014). We tested those chances and found that low evaluations of affective attributes may lead to political consumerism.

Results of the negative relationship between Russia affective attributes and political consumerism should be analyzed along with the negative relationship between FWC attributes and political consumerism. The higher the respondents perceived the FWC attributes (e.g., exciting, interesting, valuable), the less they reported political consumerism attitudes and behaviors toward 2018 FWC products. Taken together, these two significant antecedents (Russia affective attributes and FWC attributes) may create a scenario of cognitive dissonance. We have proposed that a dissonance between positive attitudes toward an event brand (the FWC) and negative perceptions of a host country's brand (attributes of Russia) might lead people to change their attitudes toward the event (the 2018 FWC) consumption. Results confirmed that proposition for affective attributes. This partially supports the application of the theory cognitive dissonance in this study. However, the lack of significance of the interaction factor as a predictor of political consumerism (Model 2) does not allow us to advocate for full cognitive dissonance.

The importance of this study for the sport marketing literature lies also in the fact that we tested both the host country's brand and the event's brand attributes in one model to explain political consumerism. Therefore, the negative effects of Russia affective brand attributes on political consumerism happens after controlling for the positive effects of FWC brand attributes. While Schofield et al. (2018) suggested that consumers of SMEs may have acted with moral disengagement to consume products related to the events, our findings show that consumers tend to reduce consumption of products related to an event when they perceive low human rights practices from the host, which is consistent with the idea that people look for a balance between their cognitions (Festinger, 1962).

\section{Practical Implications}

These results have some important practical implications for SME owners and hosts. First, for owners such as FIFA, the strategy of only improving the brand image of the event may not be sufficient to avoid political consumerism of products related to the event. Our results showed that positive perceptions of FWC brand do not prevent negative perceptions about the host affective brand attributes to lead to political consumerism. Low values of host affective brand attributes were associated with high values of political consumerism. This should send a warning signal to FIFA (and other owners, such as the IOC), who should be aware that granting hosting rights to countries with low concerns for human rights could damage the economic value of the event. Our empirical evidence supports previous conceptual articles (Lenskyj, 2016; Van Rheenen, 2014) that have already signaled to the risks of hosts with poor human rights practices. Lenskyj (2016) alerted that the IOC has damaged its reputation by ignoring constant human rights abuses in Olympic host cities 
and countries. According to Lenskyj, the IOC certainly knew about abuses against LGBT people in Russia when they granted the 2014 Games to Sochi. She mentioned that the myth of an apolitical, untouchable, and strong brand has made FIFA and IOC ignore the damages that hosts' poor human rights practices have had on their (the owners') brands.

Second, for hosts, the connection with a strong brand like the FWC may not be enough to promote the country brand to international markets. To create positive international awareness, most controversial hosts have heavily relied on the strength of the events' brands (usually FIFA or IOC) and ignored public opinion about malpractices from their governments (Brannagan \& Giulianotti, 2015; Manzenreiter, 2010). Brannagan and Giulianotti (2015) proposed that nations such as Russia and Qatar have bid to host the FWC mainly based on the belief that the association with the event brand could create international competitive advantage via soft power. They found evidence, however, to defend a thesis of soft disempowerment, which was most significantly associated with an increased global awareness about hosts' issues related to poor human rights practices.

Brannagan and Giuliannotti explored the case of Qatar as the host of the 2022 FWC, but they associated power disempowerment to other SME hosts with controversial human rights practices, namely Russia and China (host of the 2008 Beijing Olympic Games).

Manzenreiter (2010) found similar evidence of China disempowerment in the context of Beijing 2008. The association with the Olympic brand has not helped China to improve its international image, because the country has insisted on its state sovereignty, mainly concerning its relationships with Tibet and Taiwan. Other studies have shown signs of possible political consumerism, as international tourists show restrictions to travel to China, even after Beijing 2008 (Heslop, Nadeau, \& O'Reilly, 2010). To sum up, the link with strong brands like FWC and OG has not helped countries with poor human rights practices gain market benefits. Our case study with Russia and the 2018 FWC confirms this.

Another important contribution of the current study was the investigation of both intentions (before the 2018 FWC) and behaviors (after the 2018 FWC) toward political consumerism.

Recently, some sport marketing studies have advocated for investigations that move beyond intentions to actual behaviors (Shapiro, Ridinger, \& Trail, 2013; Zaharia, Biscaia, Gray, \& Stotlar, 2016). Their main argument has been that intentions might never become actual consumption. In our results, actual political consumerism behaviors did not differ from intentions. Keeping in mind that independent samples drawn in a very similar way were tested before and after the 2018 FWC, and descriptive and inferential statistics showed no difference between intentions and behaviors. Therefore, in the context of political consumerism of products related to SME, planned behaviors (Ajzen \& Fishbein, 1977) may be informative of actual behaviors. From a practical point of view, this result has particular importance for SME owners, who may use intentions toward consumption to infer actual consumption behaviors. This should give owners the opportunity to test the acceptability of hosts and make decisions about whether to grant an event to a place, even before the bidding process. Our findings suggest that a place's affective brand attributes, indicated by perceptions of poor human rights practices, are antecedents of political consumerism. Therefore, SME owners should take into consideration possible hosts' human rights practices. If humanitarian reasons have not been enough to convince them of this, the economic reasons presented in this study should.

Although Russia does not stand alone in the quest for boosting a place image, Russia does represent a modern case of political use of SME to promote a regime, which has been perceived as non-democratic (Schofield et al., 2018; Van Rheenen, 2014). For example, exploring political impacts of Sochi 2014, Persson and Petersson (2014) proposed that the official Russian discourse promoted a forceful, non-natural encounter between the myth of Russian great power and the myth of Olympism. That discourse has had a clear aim of strengthening the international political status of Russia and its president Vladimir Putin (Persson \& Petersson, 2014). Russia has tried to use the 2018 FWC to reinforce the same discourse (now in association with FIFA and football) in its quest for international political status. Results of the current research have shown that this strategy has not worked. Additionally, this study shows that, beyond international political consequences, poor human rights practices can have negative commercial effects.

\section{Limitations and Future Studies}

Some limitations of the current study and suggestions for future studies should be considered. The use of snowball sampling is a limitation, as it does not allow us to extrapolate the results to the whole population of FWC consumers. We have used two independent samples in each moment. Ideally, future studies should consider a panel longitudinal design (with the same sample being investigated over time) and the use of a random sample of FWC consumers. The small sample size in the second data collection is a limitation. 
Although the size of the second sample was small, it was larger than those used in previous sport marketing studies with two moments of data collection (i.e., Zaharia et al., 2016). It is noteworthy that, even considering only one country, delimiting the population of FWC consumers may be a very difficult task. Therefore, the use of large, non-random samples may still be the best option available to investigate consumers of SME. We have tested attributes but not benefits and attitudes toward Russia's brand. Future studies may consider Keller's (1993) theoretical framework and test whether perceptions of attributes indicate benefits and attitudes toward a host country's brand. We have not controlled for event experience. Previous studies have proposed that event experience (either attending or watching via media) might affect consumers' attitudes and behaviors (Gantz \& Wenner, 1995; Lee \& Kang, 2015). We have not controlled for fan identification, which has been reported as an important factor mainly for marketing studies involving teams and sport (Robinson, Trail, Dick, \& Gillentine, 2005; Sutton, McDonald, Milne, \& Cimperman, 1997). Results were based on Western consumers only. Future studies should consider populations of consumers in other parts of the world, which would add important information on how human rights concerns and political consumerism of SMEs have occurred in different parts of the globe.

\section{References}

Adams, A., \& Piekarz, M. (2015). Sport events and human rights: Positive promotion or negative erosion? Journal of Policy Research in Tourism, Leisure and Events, 7(3), 220-236.

Ajzen, I., \& Fishbein, M. (1977). Attitude-behavior relations: A theoretical analysis and review of empirical research. Psychological Bulletin, 84(5), 888-918.

Anderson, J. C., \& Gerbing, D. W. (1988). Structural equation modeling in practice: A review and recommended two-step approach. Psychological Bulletin, 103, 411-423.

Baumgarth, C. (2004). Evaluations of co-brands and spill-over effects: Further empirical results. Journal of Marketing Communications, 10, 115-131.

Biernacki, P., \& Waldorf, D. (1981). Snowball sampling: Problems and techniques of chain referral sampling. Sociological Methods \& Research, 10(2), 141-163.

Blackett, T., \& Boad, R. W. (1999). Co-branding: The science of alliance. London, UK: Palgrave Macmillan.

Bodet, G., \& Lacassagne, M. F. (2012). International place branding through sporting events: A British perspective of the 2008 Beijing Olympics. European Sport Management Quarterly, 12(4), 357-374.

Brannagan, P. M., \& Giulianotti, R. (2015). Soft power and soft disempowerment: Qatar, global sport and football's 2022 World Cup finals. Leisure Studies, 34(6), 703-719. https://doi. org/10.1080/02614367.2014.964291

Breaugh, J. A. (2008). Important considerations in using statistical procedures to control for nuisance variables in non-experimental studies. Human Resource Management Review, 18(4), 282-293.
Burch, L. M., Pegoraro, A., \& Frederick, E. L. (2017). The case of \#CheersToSochi. In M. Dodds, K. Heisey, \& A. Ahonen (Eds.), Routledge handbook of international sport business (pp. 251-260). London, UK: Routledge.

Chappelet, J.-L., \& Parent, M. M. (2015). The (wide) world of sports events. In M. M. Parent \& J.-L. Chappelet (Eds.), Routledge handbook of sports event management (pp. 1-17). London, UK: Routledge.

Cobbs, J., Groza, M., \& Rich, G. (2016). Brand spillover effects within a sponsor portfolio: The interaction of image congruence and portfolio size. Marketing Management Journal, 25(2), 107-122.

Copeland, L. (2014). Value change and political action: Postmaterialism, political consumerism, and political participation. American Politics Research, 42(2), 257-282.

Dahlén, M., \& Lange, F. (2005). Advertising weak and strong brands: Who gains? Psychology \& Marketing, 22(6), 473-488.

Davidson, J., \& McDonald, M. G. (2018). Rethinking human rights: The 2014 Sochi Winter Olympics, LGBT protections and the limits of cosmopolitanism. Leisure Studies, 37(1), 64-76.

Dawisha, K. (2015). Putin's kleptocracy: Who owns Russia? New York, NY: Simon and Schuster.

Dinnie, K. (2008). Nation branding: Concepts, issues, practice. Oxford, UK: Butterworth- Heinemann.

Ekberg, J., \& Strange, M. (2017). What happened to the protests? The surprising lack of visible dissent during the Sochi Winter Olympics. Sport in Society, 20(4), 532-545.

Festinger, L. (1962). A theory of cognitive dissonance (Vol. 2). Stanford, CA: Stanford University Press.

Flemming, F., Luenich, M., Marcinkowski, F., \& Starke, C. (2017). Coping with dilemma: How German sport media users respond to sport mega events in autocratic countries. International Review for the Sociology of Sport, 52(8), 1008-1024.

Florek, M., Breitbarth, T., \& Conejo, F. (2008). Mega Event = Mega Impact? Travelling fans' experience and perceptions of the 2006 FIFA World Cup host nation. Journal of Sport \& Tourism, 13(3), 199-219.

Florek, M., \& Insch, A. (2011). When fit matters: Leveraging destination and event image congruence. Journal of Hospitality Marketing \& Management, 20(3-4), 265-286.

Fornell, C., \& Larcker, D. F. (1981). Evaluating structural equation models with unobservable variables and measurement error. Journal of Marketing Research, 18, 39-50.

Friedman, M. (2002). Consumer boycotts: Effecting change through the marketplace and media. New York, NY: Routledge.

Gaffney, C. (2013). Between discourse and reality: The un-sustainability of mega-event planning. Sustainability, 5(9), 3926-3940.

Gantz, W., \& Wenner, L. A. (1995). Fanship and the television sports viewing experience. Sociology of Sport Journal, 12(1), $56-74$.

Gartner, W. C. (1993). Image formation process. Journal of Travel \& Tourism Marketing, 2(2-3), 191-216.

Gibson, H. J., Qi, C. X., \& Zhang, J. J. (2008). Destination image and intent to visit China and the 2008 Beijing Olympic games. Journal of Sport Management, 22, 427-450.

Giulianotti, R. (2004). Human rights, globalization and sentimental education: The case of sport. Sport in Society, 7(3), 355-369.

Greenwald, A. G., \& Ronis, D. L. (1978). Twenty years of cognitive dissonance: Case study of the evolution of a theory. Psychological Review, 85(1), 53.

Grix, J. (2012). 'Image' leveraging and sports mega-events: Germany and the 2006 FIFA World Cup. Journal of Sport \& Tourism, 17(4), 289-312. 
Grix, J. (2013). Sport politics and the Olympics. Political Studies Review, 11(1), 15-25. Grix, J., \& Houlihan, B. (2014). Sports mega events as part of a nation's soft power strategy: The cases of Germany (2006) and the UK (2012). The British Journal of Politics \& International Relations, 16(4), 572-596.

Hair, J. F., Black, W. C., Babin, B. J., \& Anderson, R. E. (2009). Multivariate data analysis (7th ed.). Upper Saddle River, NJ: Prentice-Hall.

Hallmann, K., \& Breuer, C. (2010). Image fit between sport events and their hosting destinations from an active sport tourist perspective and its impact on future behaviour. Journal of Sport \& Tourism, 15(3), 215-237.

Harmon-Jones, E., \& Harmon-Jones, C. (2007). Cognitive dissonance theory after 50 years of development. Zeitschrift Für Sozialpsychologie, 38(1), 7-16.

Heslop, L. A., Nadeau, J., \& O'Reilly, N. (2010). China and the Olympics: Views of insiders and outsiders. International Journal of Marketing Review, 4, 404-433.

Hoffmann, S., \& Hutter, K. (2012). Carrotmob as a new form of ethical consumption: The nature of the concept and avenues for future research. Journal of Consumer Policy, 35(2), 215-236.

Inglehart, R. (1981). Post-materialism in an environment of insecurity. American Political Science Review, 75(4), 880-900.

Inglehart, R. (1997). Modernization and postmodernization: Cultural, economic, and political change in 43 societies. Princeton, NJ: Princeton University Press.

Joergens, C. (2006). Ethical fashion: Myth or future trend? Journal of Fashion Marketing and Management: An International Journal, 10(3), 360-371.

Joreskog, K. G. (2000). Latent variable scores and their uses. Lincolnwood, IL: Scientific Software International, Inc.

Joseph, S. (2012). Social media, political change, and human rights. Boston College International \& Comparative Law Review, 35, 145.

Kim, C., \& Heere, B. (2012). Consumers from emerging markets: Perceptions and attitudes toward global sporting brands. Sport Marketing Quarterly, 21(1), 19-31.

Kirilenko, A. P., \& Stepchenkova, S. O. (2017). Sochi 2014 Olympics on Twitter: Perspectives of hosts and guests. Tourism Management, 63, 54-65.

Knott, B., Fyall, A., \& Jones, I. (2017). Sport mega-events and nation branding: Unique characteristics of the 2010 FIFA World Cup, South Africa. International Journal of Contemporary Hospitality Management, 29(3), 900-923.

Kunkel, T., Funk, D., \& Hill, B. (2013). Brand architecture, drivers of consumer involvement, and brand loyalty with professional sport leagues and teams. Journal of Sport Management, 27(3), 177-192.

Landis, R. S., Beal, D. J., \& Tesluk, P. E. (2000). A comparison of approaches to forming composite measures in structural equation modeling. Organizational Research Methods, 3(2), 186-207.

Lankina, T., Libman, A., \& Obydenkova, A. (2016). Authoritarian and democratic diffusion in post-communist regions. Comparative Political Studies, 49(12), 1599- 1629.

Lee, J. S., \& Kang, J.-H. (2015). Effects of sport event satisfaction on team identification and revisit intent. Sport Marketing Quarterly, 24(4), 225-234.

Lenskyj, H. J. (2016). Sochi 2014 Olympics: Accommodation and resistance. In J. Dart \& S. Wagg (Eds.), Sport, protest and globalisation (pp. 311-334). London, UK: Palgrave Macmillan.

Manzenreiter, W. (2010). The Beijing Games in the Western imagination of China: The weak power of soft power. Journal of Sport \& Social Issues, 34(1), 29-48. https://doi. org/10.1177/0193723509358968
Mutter, F., \& Pawlowski, T. (2014). The monetary value of the demonstration effect of professional sports. European Sport Management Quarterly, 14(2), 129-152.

Persson, E., \& Petersson, B. (2014). Political mythmaking and the 2014 Winter Olympics in Sochi: Olympism and the Russian great power myth. East European Politics, 30(2), 192-209.

Peter, L. (2017). Chechen police "kidnap and torture gay men:" LGBT activists. BBC News. Retrieved from https://www.bbc. co.uk/news/world-europe-39566136

Pielke Jr., R. (2013). How can FIFA be held accountable? Sport Management Review, 16(3), 255-267.

Podsakoff, P. M., MacKenzie, S. B., Lee, J.-Y., \& Podsakoff, N. P. (2003). Common method biases in behavioral research: A critical review of the literature and recommended remedies. Journal of Applied Psychology, 88(5), 879-903.

Reiche, D. (2018). Winter Olympics, the games of the few. Engaging Sports, 1(February).

Retrieved from https://thesocietypages.org/engagingsports/2018/02/05/ winter-olympics-the-games-of-the-few/

Robinson, M. J., Trail, G., Dick, R., \& Gillentine, A. (2005). Fans vs. spectators: An analysis of those who attend intercollegiate football games. Sport Marketing Quarterly, 14(1), 58-80.

Rocha, C. M., \& Fink, J. S. (2017). Attitudes toward attending the 2016 Olympic Games and visiting Brazil after the games. Tourism Management Perspectives, 22, 17-26. https://doi.org/ http://dx.doi.org/10.1016/j.tmp.2017.01.001

Roth, K. P., \& Diamantopoulos, A. (2009). Advancing the country image construct. Journal of Business Research, 62(7), 726-740.

Schofield, E., Rhind, D. J. A., \& Blair, R. (2018). Human rights and sports mega-events: The role of moral disengagement in spectators. Journal of Sport and Social Issues, 42(1), 3-22.

Schumacker, R. E. (2002). Latent variable interaction modeling. Structural Equation Modeling, 9(1), 40-54.

Shank, M. D., \& Beasley, F. M. (1998). Fan or fanatic: Refining a measure of sports involvement. Journal of Sport Behavior, 21(4), 435-444.

Shapiro, S. L., DeSchriver, T. D., \& Rascher, D. A. (2017). The Beckham effect: Examining the longitudinal impact of a star performer on league marketing, novelty, and scarcity. European Sport Management Quarterly, 17(5), 610-634. https://doi.or g/10.1080/16184742.2017.1329331

Shapiro, S. L., Ridinger, L. L., \& Trail, G. T. (2013). An analysis of multiple spectator consumption behaviors, identification, and future behavioral intentions within the context of a new college football program. Journal of Sport Management, 27(2), 130-145.

Sova, C. I. (2018). Discriminatory incidents in Russian football 2017-2018. SOVA Center for Information and Analysis. Retrieved from https://farenet.org/wp-content/uploads/2018/05/ FINAL-SOVA-monitoring-report_2018-6.pdf

Sutton, W. A., McDonald, M. A., Milne, G. R., \& Cimperman, J. (1997). Creating and fostering fan identification in professional sports. Sport Marketing Quarterly, 6(1), 15-22.

Tabachnick, B. G., \& Fidell, L. S. (2007). Using multivariate statistics (5th ed.). Boston, MA: Pearson/Allyn \& Bacon.

Thibault, L. (2009). Globalization of sport: An inconvenient truth. Journal of Sport Management, 23, 1-20.

Tokuyama, S., \& Greenwell, T. C. (2011). Examining similarities and differences in consumer motivation for playing and watching soccer. Sport Marketing Quarterly, 20(3), 148-156.

Tomlinson, A. (2014). The supreme leader sails on: Leadership, ethics and governance in FIFA. Sport in Society, 17(9), 1155-1169.

Tulli, U. (2016). Bringing human rights in: The campaign against the 1980 Moscow Olympic Games and the origins of the nexus between human rights and the Olympic Games. The International Journal of the History of Sport, 33(16), 2026-2045. 
Van Rheenen, D. (2014). A skunk at the garden party: The Sochi Olympics, state-sponsored homophobia and prospects for human rights through mega sporting events. Journal of Sport \& Tourism, 19(2), 127-144. https://doi.org/10.1080/14775085.2 014.949287

Walker, M., \& Kent, A. (2010). Do fans care? Assessing the influence of corporate social responsibility on consumer attitudes in the sport industry. Journal of Sport Management, 43, 743-769.

Wang, C. L., Li, D., Barnes, B. R., \& Ahn, J. (2012). Country image, product image and consumer purchase intention: Evidence from an emerging economy. International Business Review, 21(6), 1041-1051.

Watt, P. (2013). "It's not for us:" Regeneration, the 2012 Olympics and the gentrification of East London. City, 17(1), 99-118.
Wolf, E. J., Harrington, K. M., Clark, S. L., \& Miller, M. W. (2013). Sample size requirements for structural equation models: An evaluation of power, bias, and solution propriety. Educational and Psychological Measurement, 73(6), 913-934.

Worden, M. (2015). Raising the bar: Mega-sporting events and human rights. Human Rights Watch, 1-10. Retrieved from https://www.hrw.org/world-report/2015/country-chapters/ global-1

Xing, X., \& Chalip, L. (2006). Effects of hosting a sport event on destination brand: A test of co-branding and match-up models. Sport Management Review, 9, 49-78.

Yuksel, M., McDonald, M. A., \& Joo, S. (2016). Cause-related sport marketing: An organizing framework and knowledge development opportunities. European Sport Management Quarterly, 16(1), 58-85.

Zaharia, N., Biscaia, R., Gray, D., \& Stotlar, D. (2016). No more "good" intentions: Purchase behaviors in sponsorship. Journal of Sport Management, 30(2), 162-175. 